\title{
Remarks: Presidential SuCCESSION AND ImPEACHMENT: Historical PreCEDENTS, FROM INDIANA AND BEYOND
}

\author{
JOHN D. FEERICK*
}

I thank you for the opportunity to address you today on presidential succession and the impeachment provisions of the Constitution.

Two heroes in my life as a lawyer are from this state. The first is former U.S. Senator Birch Bayh, who I first met in January 1964 when the American Bar Association assembled twelve lawyers and their guests to develop a position with respect to the subjects of presidential inability and vice-presidential vacancy. Bayh became the undisputed leader of the movement for change as a way of honoring a fallen President, John F. Kennedy, whose assassination two months before the ABA conference focused the nation on the gaps in the presidential succession system. Bayh also inspired me in the importance of a lawyer rendering public service. It is inspiring for me to give these remarks below the Speaker's chair that he occupied.

The second hero is Dean James White, a longtime professor at this law school, who served for thirty years as a consultant to the ABA in the areas of admission to the bar and legal education. He helped me transform from a practicing lawyer to an academic lawyer as a dean and professor at Fordham Law School.

Today's program on Indiana's Vice Presidents of the United States is also part of my Indiana history. In 1966, I was asked to write a book for high school students, a first of its kind, on the vice presidents, which I proceeded to do with the help of my wife, Emalie. ${ }^{1}$ I learned in the process of four of the six Vice Presidents from Indiana: Schuyler Colfax, Thomas Hendricks, Charles Fairbanks, and Thomas Marshall. Since I wrote my book, two more Indiana Vice Presidents have been elected: Dan Quayle and current Vice President, Michael Pence.

All six, interestingly enough, were part of, or at least impacted by, presidential succession or impeachment events. Schuyler Colfax was the Speaker of the House during President Andrew Johnson's impeachment in $1868 .^{2}$ Five years later, when Colfax was serving as Ulysses S. Grant's Vice President, a

* Norris Professor of Law and Dean Emeritus, Fordham University School of Law. I wish to express my deep gratitude to two individuals for helping me with my speech at the Indiana Law Review symposium on March 28, 2018 and this article: my colleague on the adjunct faculty, John Rogan, and William Pierotti of the Fordham Law School Class of 2019. Without their assistance with research, drafting and editing, the speech and article would not have been possible. I also wish to thank former Vice President Dan Quayle for allowing me to interview him concerning the subject of presidential inability. It was a great honor for me to have that opportunity, the results of which can be found in this article.

1. John D. Feerick \& Emalie P. Feerick, The Vice-Presidents of the United States (1967).

2. Schuyler Colfax, 17th Vice President (1869-1873), U.S. SENATE, https://www.senate.gov/ artandhistory/history/common/generic/VP_Schuyler_Colfax.htm [https://perma.cc/Q2DR-9V6Y] (last visited Oct. 6, 2018). 
House committee considered impeaching Colfax for allegedly receiving a bribe when he was in Congress. ${ }^{3}$ Before his involvement with impeachment, Colfax witnessed a tragic moment in the country's presidential succession history when he was in the room where President Lincoln died in $1865 .^{4}$

The second Indiana Vice President, Thomas Hendricks, died in office in 1885 , providing an impetus for Congress to change the line of succession, which had been left empty by Hendricks' passing. Hendricks' death also illustrated the problem of vice-presidential vacancy. ${ }^{5}$

Charles Fairbanks was Vice President to Theodore Roosevelt, who had succeeded to the presidency after President William McKinley's assassination in 1901. ${ }^{6}$ The McKinley assassination may have had a significant impact on Fairbanks' career. When Fairbanks was a Senator, he was a political ally of McKinley, and was seen as a possible successor to him - until the assassination. ${ }^{7}$

Thomas Marshall, the fourth Indiana Vice President, was in office when Woodrow Wilson suffered a stroke that incapacitated him for the final year-anda-half of his term. Marshall resisted calls to act as president during Wilson's inability, in part due to the lack of procedures for declaring a presidential inability. ${ }^{8}$

Vice President Dan Quayle took part in an unprecedented planning for uses of the Twenty-Fifth Amendment by meeting with President George H.W. Bush at the start of their terms in 1989 to discuss how the amendment should be used. ${ }^{9}$

Current Vice President Pence serves when calls for impeachment and use of the Twenty-Fifth Amendment occur from time to time. ${ }^{10}$

The first part of my remarks addresses the Twenty-Fifth Amendment, Senator Bayh's great achievement, and the second part addresses presidential impeachment.

3. Id.

4. Id.

5. John D. Feerick, The Twenty-Fifth Amendment: Its Complete History and Applications 38 (3d ed. 2014) [hereinafter Twenty-Fifth AmENDMENT].

6. Charles Warren Fairbanks, 26th Vice President (1905-1909), U.S. SENATE, https://www. senate.gov/artandhistory/history/common/generic/VP_Charles_Fairbanks.htm [https://perma.cc/QUK8-V4X6] (last visited Oct. 6, 2018).

7. $I d$.

8. See Twenty-Fifth Amendment, supra note 5, at 14-16.

9. Twenty-Fifth Amendment, supra note 5, at 200-02. In an interview with former Vice President Quayle that I conducted for this article, he described the meeting on Twenty-Fifth Amendment planning and other experiences during the first Bush administration. Excerpts from the interview are in Appendix A.

10. See, e.g., Ross Douthat, The 25th Amendment Solution for Removing Trump, N.Y. TIMES (May 16, 2017), https:/www.nytimes.com/2017/05/16/opinion/25th-amendment-trump.html [https://perma.cc/QGA4-6W9W]; Christina Marcos, House Rejects Democrat's Resolution to Impeach Trump, HiLl (Dec. 6, 2017), http://thehill.com/homenews/house/363544-house-rejectsdemocratic-resolution-to-impeach-trump [https://perma.cc/6S8Q-ZHN2]. 


\section{PRESIDENTIAL SUCCESSION}

As the framers drafted the Constitution, they wisely anticipated that the President might die, resign, be removed, or suffer an inability in office. To provide for these contingencies, they included Article II, Section 1, Clause 6, which states,

In Case of the Removal of the President from Office, or of his Death, Resignation, or Inability to discharge the Powers and Duties of the said Office, the Same shall devolve on the Vice President, and the Congress may by Law provide for the Case of Removal, Death, Resignation or Inability, both of the President and Vice President, declaring what Officer shall then act as President, and such Officer shall act accordingly, until the Disability be removed, or a President shall be elected. ${ }^{11}$

In sum, the Succession Clause made the Vice President the first successor to the presidency in the event of the President's death, resignation, removal or inability. It also gave Congress the power to appoint successors beyond the Vice President for situations when both the President and Vice President vacated their offices or became disabled.

But there were significant ambiguities and gaps in the Succession Clause. First, it was unclear about the Vice President's status after succession. Was it the President's "Office" that devolved on the Vice President in cases of removal, death, resignation and inability or merely the President's "Powers and Duties"? This distinction may not have had much practical consequence in cases of death, resignation or removal. However, it was problematic when the President became disabled. If the President's office and title devolved on the Vice President, the disabled President might not be able to return to it, even if he recovered.

Another ambiguity in the Succession Clause was the lack of guidance for identifying presidential inabilities. Although the clause listed "Inability" as a case for succession, it did not define inability or provide a way to declare its existence and termination, which made it harder for the Vice President to assume presidential power when the president became disabled.

The Succession Clause also created a debate that continues to this day about which officials Congress can appoint as presidential successors. The clause empowered Congress to "declar[e] what Officer shall act as President" after the President and Vice President. ${ }^{12}$ Many, including framers like James Madison, have interpreted "Officer" to refer to non-legislators. ${ }^{13}$ This interpretation views

11. U.S. Const. art. II, $\S 1$, cl. 6.

12. Id.

13. See Continuity of Gov't Comm'n, Preserving Our Institutions: The Second REPORT OF THE CONTINUITY OF GOVERnMENT COMMISSION 26 (2009), https://www.brookings. edu/wp-content/uploads/2016/06/06_continuity_of_government.pdf[https://perma.cc/P2EF-R7U3]; John D. Feerick, From Failing Hands: The Story of Presidential Succession 61-62 (1965) (quoting James Madison) [hereinafter From FAILING Hands]; Akhil Reed Amar \& Vikram David Amar, Is the Presidential Succession Law Constitutional?, 48 StAn. L. REV. 113, 114-17 (1995); 
the term "Officer" as shorthand for "Officers of the United States"-a constitutional phrase that refers to executive branch officials and judges. ${ }^{14}$ Others view the "Officer" term as open to a broader interpretation that includes members of Congress. They point to constitutional provisions that call members of Congress "officers." 15

Despite concerns about the constitutionality of legislators serving as successors, the first Congress created a line of succession listing the Senate President pro tempore followed by the Speaker of the House. ${ }^{16}$ The death of Vice President Hendricks played a role, as noted, in Congress changing the 1792 succession law. His death in office in November 1885 left the line of succession completely vacant: there was no longer a Vice President, and Congress had not convened to choose a President pro tempore and Speaker of the House. ${ }^{17}$

When Congress returned to session in December 1885, it quickly focused on the vacant line of succession as well as the constitutional concerns with having legislators as successors. Only two months after Hendricks' passing, in January 1886, it passed a new line of succession comprised only of Cabinet Secretaries listed in the order of the creation of their departments. ${ }^{18}$ That line remained in place until 1947, when Congress created the current line of succession. ${ }^{19}$ The Presidential Succession Act of 1947 retained the Cabinet Secretaries as successors, but returned congressional leaders to the line, placing the Speaker of the House first in the line after the Vice President and the Senate President pro tempore second. ${ }^{20}$ This statute kept one of the Succession Clause's major ambiguities - the meaning of "Officer"-looming over the nation's presidential succession framework. It also includes a requirement of questionable constitutionality that a Cabinet member who has succeeded to the presidency be "bumped" from being Acting President as soon as a new Speaker or President pro

Ruth C. Silva, The Presidential Succession Act of 1947, 47 Mich. L. REv. 451, 457-75 (1949).

14. Fordham Univ. Sch. of Law's Clinic on Presidential Succession, Ensuring the Stability of Presidential Succession in the Modern Era, 81 FordHAM L. REV. 1, 37 (2012) [hereinafter First Fordham Clinic Report].

15. See Joel K. Goldstein, Taking from the Twenty-Fifth Amendment: Lessons in Ensuring Presidential Continuity, 79 FordHAM L. REV. 959, 1019-27 (2010).

16. Presidential Succession Act of 1792, ch. 8, 1 Stat. 239, 240 (repealed 1886).

17. See Twenty-Fifth Amendment, supra note 5, at 38 .

18. Id. at 38-40; see also Presidential Succession Act of 1886, ch. 4, 24 Stat. 1, 1 (repealed 1947).

19. After President Franklin D. Roosevelt died in office and Harry Truman succeeded to the presidency in 1945, the next person in the line of the succession was the Secretary of State. The presence of an unelected official in that spot led Truman to call on Congress to return legislators to the line. See Harry S. Truman, Question of the Presidential Succession: Message from the President of the United States: Transmitting Request for Legislation Dealing with the Question of the Presidential Succession, H.R. Doc. No. 246 (1945), available at https://ir.lawnet.fordham.edu/cgi/viewcontent.cgi?article=1006\&context=twentyfifth_amendme nt_executive_materials [https://perma.cc/ZM6Z-Y9H3].

20. Presidential Succession Act of 1947, 3 U.S.C. § 19(d)(1) (2019). 
tempore is chosen. ${ }^{21}$

Thankfully, not all of the Succession Clause's ambiguities and gaps are still with us. The Twenty-Fifth Amendment addressed most of them - but not before those issues were revealed by tragedies.

In 1841, President William Henry Harrison succumbed to pneumonia only a month after his inauguration, becoming the first president to die in office. Vice President John Tyler asserted that under the Succession Clause he had become President, instead of acting president, for the rest of Harrison's term. Some members of Congress objected. They seized on the Succession Clause's ambiguous language about the Vice President's post-succession status. But Tyler did not back down, and his claim that he had become President for the rest of the term set a precedent that would complicate future disability crises. ${ }^{22}$ The precedent was further solidified by Vice President Millard Fillmore's succession to the presidency after President Zachary Taylor's death in 1850, and Vice President Andrew Johnson's succession after President Abraham Lincoln's assassination in $1865 .^{23}$

Sixteen years after the Lincoln assassination, President James Garfield was shot and wavered between life and death for nearly three months, ${ }^{24}$ yet Vice President Chester Arthur resisted acting as president. There were several reasons for Arthur's hesitancy-including that Garfield's assassin exclaimed, immediately after firing on the President, that Arthur would be president. ${ }^{25}$ But the Tyler precedent and the Succession Clause's shortcomings made the situation especially challenging.

In the weeks after the shooting, Garfield's doctor issued a stream of misleading statements indicating that Garfield's condition was improving. ${ }^{26}$ The hope that Garfield might fully recover made the Tyler precedent an important factor as the Cabinet and Arthur decided what to do. ${ }^{27}$ If Arthur acted as president, the precedent indicated that he would become president and permanently displace Garfield, regardless of whether he recovered-a result which seemed unconscionable as the country was pulling for Garfield's recovery.

Even if Arthur had wanted to take over presidential powers and duties, the lack of both constitutional procedures and a definition of "inability" made it hard for him to do so. Arthur did not assume the presidency until Garfield's death,

21. Id. $§ 19(d)(2)$; Second Fordham Univ. Sch. of Law Clinic on Presidential Succession, Fifty Years After the Twenty-Fifth Amendment: Recommendations for Improving the Presidential Succession System, 86 FordHAM L. REV. 917, 949-50 (2017) [hereinafter Second Fordham Clinic Report].

22. See John D. Feerick, Presidential Inability: Filling in the Gaps, 33 Pol. \& LifE SCI. 11, 12-13 (2014) [hereinafter Presidential Inability].

23. Twenty-Fifth AMENDMENT, supra note 5, at 8.

24. See generally Candice Millard, Destiny of the Republic: A Tale of Madness, Medicine and the Murder of a President (2011).

25. From FaILING Hands, supra note 13, at 118.

26. MiLlaRD, supra note 24, at 227-28.

27. Twenty-Fifth Amendment, supra note 5, at 9. 
eighty days after Garfield had been shot.

Nearly fifty years after Garfield's death, on October 2, 1919, President Woodrow Wilson suffered a stroke that partially paralyzed him and set off another presidential inability crisis. Wilson was left unable to discharge the powers and duties of office for the nearly year-and-a-half remaining in his term. ${ }^{28}$ The third Indiana Vice President, Thomas Marshall, had to navigate many of the same challenges that Chester Arthur faced before him. ${ }^{29}$

But, unlike during Garfield's inability, Wilson and his closest associates aggressively resisted attempts to have the Vice President act as president. Secretary of State Robert Lansing suggested that Wilson's doctor or secretary certify that Wilson was disabled so Marshall could act as President, but Wilson's closest aides rejected the idea. ${ }^{30}$ Wilson demanded Lansing's resignation a few months later after learning that Lansing had called Cabinet meetings to handle pressing matters in Wilson's absence. ${ }^{31}$ Matters that the Cabinet did not address were mostly handled by Wilson's wife, Edith. ${ }^{32}$

The lack of procedures for declaring the president unable made a transfer of power nearly impossible. If Marshall had asserted that he was acting as president, there is little doubt that Wilson and his allies would have challenged him.

The Succession Clause's ambiguities and gaps were again problematic during the Eisenhower administration. Eisenhower suffered three serious health episodes: a heart attack in 1955; intestinal inflammation that required surgery in 1956; and a stroke in $1957 .{ }^{33}$ After his stroke, he grew deeply concerned about his health and the lack of constitutional procedures for handling presidential inabilities. ${ }^{34}$

He responded with a "letter agreement" between him and Vice President Richard Nixon. ${ }^{35}$ The agreement allowed Eisenhower, if disabled, to transfer the powers of the presidency to Nixon. If Eisenhower could not communicate that he was disabled, the agreement authorized Nixon to discharge the office's powers and duties after appropriate consultation. In both cases, the agreement called for Nixon to serve as Acting President and gave Eisenhower the power to determine the end of an inability. ${ }^{36}$

28. Id. at 15-16.

29. See generally Joel K. Goldstein, Vice-Presidential Behavior in a Disability Crisis: The Case of Thomas R. Marshall, 33 PoL. \& LifE SCI. 37 (2014).

30. From FAILING HANDS, supra note 13, at 170-72.

31. See Goldstein, supra note 29 , at 44.

32. In fact, a recent book called Madam President asserts that she took such a significant role that she was essentially the nation's first woman president. See William Hazelgrove, Madam President: The Secret Presidency of Edith Wilson (2016).

33. See John D. Feerick, Presidential Succession and Inability: Before and After the TwentyFifth Amendment, 79 Fordham L. ReV. 907, 921 (2010) [hereinafter Presidential Succession and Inability].

34. Id.

35. Id.

36. Id. at $921-22$. 
The "letter agreement" was a significant advance in resolving the gaps and ambiguities in the Succession Clause and provided ideas that influenced the Twenty-Fifth Amendment's development. But the "letter agreement" suffered from major flaws, especially the absence of checks on the President's power to declare the end of an inability. It also did not have the force of law behind it. Congressional hearings on presidential succession occurred in the final years of the Eisenhower administration, but no legislation ensued. ${ }^{37}$

The assassination of President John F. Kennedy in 1963 finally spurred action. With Eisenhower's health problems fresh in lawmakers' minds, the assassination again raised the prospect of a presidential inability crisis. If the assassin's bullet had struck Kennedy slightly differently, he could have been left alive, but incapacitated, just like President Garfield. ${ }^{38}$

Under Birch Bayh's leadership, ${ }^{39}$ Congress opened hearings in 1964 on presidential inability, ${ }^{40}$ and the ABA convened a conference on the subject. The ABA conference - of which I was privileged to be part-worked closely with Congress, particularly Senator Bayh, in crafting and building support for what became the Twenty-Fifth Amendment. ${ }^{41}$ On July 6, 1965, Congress approved the proposed amendment, ${ }^{42}$ and it was ratified on February $10,1967^{43}$ and proclaimed by President Lyndon Johnson on February 23, $1967 .^{44}$

The amendment has four sections. Section 1 provides that the Vice President

37. Twenty-Fifth Amendment, supra note 5, at 50-53; see also Presidential Inability: Hearings Before the Subcomm. on Constitutional Amendments of the S. Comm. on the Judiciary, 85th Cong. (1958); Presidential Inability: Hearing Before the Special Subcomm. on Study of Presidential Inability of the H. Comm. on the Judiciary, 85th Cong. (1957); Presidential Inability: Hearings Before Special Subcomm. to Study Presidential Inability of the H. Comm. on the Judiciary, 84th Cong. (1956).

38. Twenty-Fifth Amendment, supra note 5, at 55. Although the Kennedy assassination was the pivotal catalyst for the Twenty-Fifth Amendment's development, mounting anxiety over the rise of the nuclear age likely also played a very significant role. See Rebecca C. Lubot, " $A D r$. Strangelove Situation": Nuclear Anxiety, Presidential Fallibility, and the Twenty-Fifth Amendment, 86 FordHAM L. REV. 1175 (2017).

39. Senator Bayh provides a full account of his work on the Twenty-Fifth Amendment in his book One Heartbeat Away. See Birch Bayh, One Heartbeat Away: Presidential Disability AND SUCCESSION (1968).

40. See Presidential Inability and Vacancies in the Office of Vice President: Hearings Before the Subcomm. on Constitutional Amendment of the S. Comm. on the Judiciary, 88th Cong. (1964), https://ir.lawnet.fordham.edu/cgi/viewcontent.cgi?article=1006\&context=twentyfifth_amendme nt_congressional_materials [https://perma.cc/4HYW-3JGC].

41. John D. Feerick, The Twenty-Fifth Amendment: A Personal Remembrance, 86 FordHAM L. REV. 1075 (2017).

42. 111 CONG. ReC. 15,596 (1965).

43. Twenty-Fifth AMENDMENT, supra note 5, at 105.

44. See Lyndon B. Johnson, Public Papers of the Presidents of the United States: LYNDON B. JOHNSON 217-18 (1968). 
becomes President if the President dies, resigns, or is removed from office. ${ }^{45}$ By listing the only contingencies where the Vice President becomes President, Section 1 resolves the issues stemming from the Tyler precedent. The Amendment's inability provisions in Sections 3 and 4 make clear that the Vice President acts as President only when the President is disabled. ${ }^{46}$ Section 1 was used on August 9, 1974 when Vice President Gerald R. Ford succeeded to the presidency upon President Richard Nixon's resignation. ${ }^{47}$

Section 2 allows the President to fill a vacancy in the vice presidency. Under this section, the President's nominee must receive approval from majorities of both the House of Representatives and the Senate. ${ }^{48}$ Before the Twenty-Fifth Amendment's ratification, sixteen Vice Presidents did not finish their terms: eight succeeded to the presidency, seven died, and one resigned. Those vacancies left the country without a Vice President for more than 37 combined years. ${ }^{49}$ Section 2 has been used twice: first when President Nixon nominated Gerald Ford to be Vice President following Spiro Agnew's resignation in 1973 and then when President Ford nominated Nelson Rockefeller to be Vice President following Ford's succession to the presidency upon Nixon's resignation in $1974 .^{50}$

Section 3 allows the President, on his own initiative, to temporarily transfer presidential power to the Vice President by submitting a written declaration of inability to the Speaker of the House and Senate President pro tempore. The President can return to the office's powers and duties by submitting another written declaration to the same officials. ${ }^{51}$ President Ronald Reagan invoked Section 3 to transfer power to Vice President George H.W. Bush prior to undergoing cancer surgery in 1985, ${ }^{52}$ and President George W. Bush invoked the provision to transfer power to Vice President Dick Cheney before colonoscopies in 2002 and $2007 .^{53}$

Section 4 is the provision that has been the focus of recent discussion of the Twenty-Fifth Amendment. It allows for the President's temporary removal from presidential power if he is unable or unwilling to invoke Section 3. When the Vice President and a majority of the Cabinet submit a declaration to the Speaker of the House and Senate President pro tempore stating that the President is unable, the Vice President becomes Acting President. ${ }^{54}$ When the President submits a declaration that he is not unable, the Vice President and Cabinet have

45. U.S. CONST. amend. XXV, $\S 1$.

46. See U.S. Const. amend. XXV, §§ 3-4.

47. Twenty-Fifth AmEndment, supra note 5, at 164-65.

48. See U.S. Const. amend. XXV, § 2.

49. Twenty-Fifth AMENDMENT, supra note 5, at 313-14.

50. Goldstein, supra note 15, at 970-72.

51. See U.S. Const. amend. XXV, § 3.

52. Twenty-Fifth Amendment, supra note 5, at 196-99.

53. Id. at 202-03; see also Second Fordham Clinic Report, supra note 21, at 926-27 (noting instances when presidents considered using Section 3, but did not ultimately invoke it).

54. See U.S. Const. amend. XXV, § 4. 
four days to consider whether to reassert that the President is unable..$^{55}$ If they do not make another inability declaration in that four-day period, the President returns to power. ${ }^{56}$ If they submit another declaration reasserting that the President is unable, Congress must "decide the issue" ${ }^{57}$ within twenty-one days. If two-thirds of both houses of Congress do not concur that the President is unable, the President returns to power. ${ }^{58}$ If two-thirds conclude that the President is unable, he remains out of power. ${ }^{59}$ During the four-day and twenty-one-day periods, the Vice President continues to serve as Acting President. ${ }^{60}$ The process can be reactivated at any time by either the President or Vice President and Cabinet. ${ }^{61}$ Section 4 has never been used, but White House officials did discuss its invocation following the assassination attempt on President Reagan in $1981 .^{62}$

The Twenty-Fifth Amendment does not clarify the ambiguity in the Succession Clause regarding what constitutes inability. This was not an oversight. The amendment's framers left "Inability" undefined to provide flexibility for future scenarios that they could not predict. ${ }^{63}$ But the framers did have a general concept of situations where invocation of the amendment would be appropriate. ${ }^{64}$ They were influenced by President Eisenhower's view of conditions that might constitute inabilities. In an accompanying memorandum to his letter agreement with Vice President Nixon, Eisenhower identified several situations that might require transfers of power, including "disease or accident that would prevent the President from making important decisions," break downs in communications between a travelling President and the Capital, and situations where the President's location was unknown, such as might occur if Air Force One crashed. ${ }^{65}$ He said he would resign if he became permanently disabled. ${ }^{66}$

The terms "unable" and "inability" in the Twenty-Fifth Amendment were

55. Id.

56. $I d$.

57. How Congress would go about "decid[ing] the issue" had received little scholarly attention until recently, when students in Fordham Law School's Second Presidential Succession Clinic and Yale Law School's Rule of Law Clinic evaluated the issue in their respective works. See Yale Law Sch. Rule of Law Clinic, The Twenty-Fifth Amendment to the United States COnstitution: A ReAder's Guide 50-62 (2018), available at https:/law.yale.edu/system/ files/area/clinic/document/mn082208_ls_readerguide_interior_final.pdf [https://perma.cc/NC9S5FUS]; Second Fordham Clinic Report, supra note 21, at 971-87.

58. See U.S. CONST. amend. XXV, § 4.

59. Id.

60. Id.

61. Id.

62. Twenty-FIFTh AMENDMENT, supra note 5, at 193-96.

63. Presidential Succession and Inability, supra note 33, at 925.

64. See id. at 925-26; Twenty-Fifth AmEndment, supra note 5, at 115-17; see also Second Fordham Clinic Report, supra note 21, at 928-29.

65. See First Fordham Clinic Report, supra note 14, at 77-79 (full text of letter agreement and accompanying memorandum).

66. See id. 
"intended to cover all cases in which some condition or circumstance prevents the President from discharging his powers and duties." ${ }^{67}$ Physical and mental illness, both temporary and permanent, were covered.$^{68}$ Senator Bayh said inability in Section 4 referred to an "impairment of the President's faculties" that made him "unable either to make or communicate his decisions as to his own competency to execute the powers and duties of his Office." 69

Circumstances - not just the president's condition - might be relevant to determining whether an inability exists. Senator Bayh provided an example during the debates on the amendment, stating, "A President who was unconscious for 30 minutes when missiles were flying toward this country might only be disabled temporarily, but it would be of severe consequence when viewed in light of the problems facing the country." 70

The amendment's framers noted some circumstances where invocation of the amendment would not be appropriate. They were clear that unpopularity, incompetence, impeachable conduct, policy and political differences, poor judgment, and laziness do not constitute "inabilities."

The Twenty-Fifth Amendment immensely improved the presidential succession system, but further reform is still needed. Over the last three decades, two commissions, ${ }^{72}$ three law school clinics, ${ }^{73}$ and a working group ${ }^{74}$ have developed proposals and guidance to ensure that the nation is prepared for an array of presidential succession scenarios. ${ }^{75}$ Senator Bayh has contributed to

67. John D. Feerick, A Response to Akhil Reed Amar's Address on Applications and Implications of the Twenty-Fifth Amendment, 47 Hous. L. REV. 41, 53 (2010).

68. See Twenty-Fifth Amendment, supra note 5, at 115.

69. Id.

70. Id. at 116 .

71. Presidential Succession and Inability, supra note 33, at 926.

72. See Miller Ctr. Comm'n No. 4, Report of the Commission on Presidential DisABILITY AND THE TwENTY-FIFTH AMENDMENT (1988), http://web1.millercenter.org/ commissions/comm_1988.pdf [https://perma.cc/4GKR-KWJ2]; CONTINUITY OF GOV'T COMM'N, supra note 13.

73. See First Fordham Clinic Report, supra note 14; Second Fordham Clinic Report, supra note 21; YAle Law SCH. Rule of LAW Clinic, supra note 57.

74. See Presidential Disability: Papers, Discussions, and Recommendations on the Twenty-Fifth Amendment and Issues of InABILITy and Disability in Presidents of the United StATES (James F. Toole \& Robert J. Joynt eds., 2001).

75. In addition to the work done by expert and student groups, individuals have advanced many recommendations for improving the succession system in the decades since the Twenty-Fifth Amendment's ratification. See, e.g., James M. Ronan, Living Dangerously: The Uncertainties of Presidential Disability and Succession (2015); Roy E. Brownell II, What to Do If Simultaneous Presidential and Vice Presidential Inability Struck Today, 86 FordHAm L. Rev. 1027 (2017); Robert E. Gilbert, Presidential Disability and the Twenty-Fifth Amendment: The Difficulties Posed By Psychological Illness, 79 Fordham L. REV. 843 (2010); Norman Ornstein, A Better Way on Presidential Succession, WASH. Post (Mar. 3, 2007), http://www.washingtonpost. com/wp-dyn/content/article/2007/03/02/AR2007030201141.html [https://perma.cc/7BZE-DUM6]; 
almost all of these efforts. In fact, he co-chaired the first such initiative- the Miller Center Commission on Presidential Disability and the Twenty-Fifth Amendment, which issued its recommendations in $1988 .^{76}$ The Commission called on the White House to create plans for using the Twenty-Fifth Amendment. ${ }^{77}$ That recommendation was inspired by the failure to invoke the amendment after the Reagan assassination attempt. ${ }^{78}$

Against the backdrop of these recommendations, President George H.W. Bush and Vice President Dan Quayle convened a meeting at the start of the Bush administration to discuss how they would handle situations where the president became disabled. ${ }^{79}$ Vice President Quayle recalled in an interview for this article that the hour-long meeting involved the White House Counsel explaining how invocations of the Twenty-Fifth Amendment would work. ${ }^{80} \mathrm{He}$ said the Bush administration's approach did not involve any signed agreements in which the parties bound themselves to proceed in a certain manner if the Twenty-Fifth Amendment was implicated. ${ }^{81}$ Rather, the Bush administration relied on reaching consensus and coordinating through the Chief of Staff. ${ }^{82}$ In considering how to use the Twenty-Fifth Amendment, the fifth Indiana Vice President was planning for uses of an amendment that a former Indiana Senator had guided to ratification.

Students at Fordham Law School have been grateful beneficiaries of Senator Bayh's lifelong commitment to succession issues. He spoke with the students in both of the clinics on presidential succession that I co-taught; ${ }^{83}$ spoke to the editors of the Fordham Law Review for an oral history of succession $;{ }^{84}$ and gave remarks and sat on all of the panels at a two-day symposium in $2010 .{ }^{85}$ Fordham held another symposium in fall 2017 to mark the $50^{\text {th }}$ anniversary of the TwentyFifth Amendment's ratification, ${ }^{86}$ and the Fordham Law Review dedicated the

Amar \& Amar, supra note 13; Goldstein, supra note 15; Presidential Inability, supra note 22.

76. See Miller Ctr. Comm'N No. 4, supra note 72.

77. Id. at 4 .

78. See id. at 4-6; Twenty-Fifth Amendment, supra note 5, at 221-24 (summarizing and listing the Miller Commission's recommendations).

79. Twenty-Fifth AmENDMENT, supra note 5, at 200-01.

80. See Appendix A (quoting excerpts from the interview with Vice President Quayle).

81. Id.

82. Id.

83. First Fordham Clinic Report, supra note 14, at 7-8; Second Fordham Clinic Report, supra note 21 , at 921 .

84. A Modern Father of Our Constitution: An Interview with Former Senator Birch Bayh, 79 Fordham L. Rev. 781 (2010) [hereinafter A Modern Father of Our Constitution] (interview with Senator Bayh published as part of the 2010 symposium).

85. See Remarks from Senator Birch Bayh, 79 FordhAm L. ReV. 1091 (2010); see also Symposium: The Adequacy of the Presidential Succession System in the 21 $1^{\text {st }}$ Century, Part 1, Fordham L. ARChive Scholarship \& Hist. (Apr. 10, 2010), https://ir.lawnet.fordham.edu/ twentyfifth_amendment_photos/2/ [https://perma.cc/M2TQ-A6XV] (video of Senator Bayh's remarks); A Modern Father of Our Constitution, supra note 84.

86. See Matthew Diller, Symposium: Continuity in the Presidency: Gaps and Solutions, 86 
resulting symposium issue to Senator Bayh. ${ }^{87}$

Senator Bayh received other honors tied to the Twenty-Fifth Amendment's anniversary in 2017. The American Bar Association awarded him with a Presidential Citation and the Bipartisan Policy Center issued a letter commendation recognizing his work on the amendment. ${ }^{88}$ And Indiana's senior Senator, Joseph Donnelly, honored Senator Bayh in remarks on the Senate floor. ${ }^{89}$

It takes a wide range of talents for a legislator to be as successful as Senator Bayh. It is not by accident that a Senator frames two constitutional amendments - more than anyone since James Madison. ${ }^{90}$ In fact, Senator Bayh was nearly responsible for three amendments. The Equal Rights Amendment was adopted by Congress and would have been added to the Constitution if only a handful of additional states had approved it. ${ }^{91}$ Senator Bayh also had great influence as the Constitution's gatekeeper, using his role as Chairman of the Subcommittee on Constitutional Amendments to keep some amendments out of the Constitution.

One of Senator Bayh's great skills that I saw when I watched him craft and build support for the Twenty-Fifth Amendment was his ability to foster consensus, especially across party lines. The Twenty-Fifth Amendment was a truly bipartisan effort. ${ }^{92}$ Democrats and Republicans worked together to address serious vulnerabilities that made the nation less secure. As the Twenty-Fifth Amendment enters its second half-century in the Constitution, we should hope that lawmakers follow Senator Bayh's model to further strengthen the succession system.

\section{IMPEACHMENT}

Turning to the impeachment provisions, the Constitution states in Article II, $\S 4$, "[t]he President, Vice President and all civil Officers of the United States, shall be removed from Office on Impeachment for, and Conviction of, Treason,

FORDHAM L. REV. 911 (2017).

87. John D. Feerick, Dedication to Senator Birch E. Bayh, 86 Fordham L. Rev. 907 (2017).

88. See The First 50 Years of the 25th Amendment, Part 1, Fordham L. ArChive SCHOLARSHIP \& HisT. (May 10, 2017), https://ir.lawnet.fordham.edu/twentyfifth_amendment photos/6/ [https://perma.cc/6JU8-FVNH] (video recording of the award presentations).

89. 163 Cong. REC. S2046 (daily ed. Mar. 28, 2017) (statement of Sen. Donnelly).

90. Jesse Wegman, The Man Who Changed the Constitution, Twice, N.Y. Times (Mar. 14, 2019), https://www.nytimes.com/2019/03/14/opinion/birch-bayh-constitution.html [https://perma.cc/FLV8-HKG3].

91. See Robinson Woodward-Burns, The Equal Rights Amendment is One State from Ratification. Now What?, WaSH. Post (Jun. 20, 2018), https://www.washingtonpost.com/news/ monkey-cage/wp/2018/06/20/the-equal-rights-amendment-is-one-state-from-ratification-nowwhat/?utm_term=.d5fcd61f4ed4 [https://perma.cc/E27L-A7EC].

92. See Joel K. Goldstein, The Bipartisan Bayh Amendment: Republican Contributions to the Twenty-Fifth Amendment, 86 FordHAM L. REV. 1137 (2017). 
Bribery, or other high Crimes and Misdemeanors." ${ }^{93}$ In combination with the sections in Article I granting the House "the sole Power of Impeachment" the Senate the "sole Power to try all Impeachments," ${ }^{95}$ Congress is provided with a mechanism to remove Executive and Judicial branch members in the appropriate circumstances.

The brevity of these Sections belies the consequential authority Congress is granted. But this authority must be read against a backdrop stretching back centuries. ${ }^{96}$ The Framers considered this history as they measured the words of these Sections. ${ }^{97}$ Since the early days of our Nation, this history and the Framers' deliberations have informed its continuing exposition. When the House and Senate exercise these powers, they look back to their roots as they proceed through a complex process and grapple with the recurring question of what precisely constitutes an impeachable offense.

\section{A. The Process of Impeachment and Conviction}

A sketch of the underlying processes and procedures by which the House impeaches and the Senate convicts is instructive. The process notably shares some surface similarities with criminal justice procedures. ${ }^{98}$ For example, the House might be viewed as similar to a grand jury issuing an indictment, while the Senate trial and judgment shares some similarities with a petit jury, as the finders of fact, and judge, as the administrator of the process and arbiter of the law. ${ }^{99}$ However, it is important to recognize that despite these similarities, impeachment and conviction remain distinct, unique, and, above all, political processes. ${ }^{100}$ Impeachment and conviction do not preclude criminal indictment and conviction. ${ }^{101}$ And impeachment and conviction result only in removal from office, with the possibility of being barred from holding future office if the Senate votes in favor of this additional sanction. ${ }^{102}$ The primary purpose is to safeguard the integrity of the American constitutional system, not to punish. ${ }^{103}$

1. The Role of the House of Representatives.-Article I of the Constitution

93. U.S. CONST. art. II, $\S 4$.

94. U.S. CONST. art. I, $\S 2$, cl. 5.

95. U.S. CONST. art I, § 3, cl. 6.

96. Elizabeth B. Bazan, Cong. Research Serv., 98-186, Impeachment: An Overview of Constitutional Provisions, Procedure, and Practice 7 (2010).

97. John D. Feerick, Impeaching Federal Judges: A Study of the Constitutional Provisions, 39 FordHAM L. REV. 1, 15-23 (1970) [hereinafter Impeaching Federal Judges].

98. Susan Navarro Smelcer, Cong. Research Serv., R41172, The Role of the Senate in Judicial Impeachment Proceedings: Procedure, Practice, and Data 3 (2010).

99. Id.

100. Id.

101. Id.

102. Id.

103. S. REP. No. 101-1, at 19 (1989); see also BAZAN, supra note 96, at 7; SMELCER, supra note 98 , at 3 . 
allocates, as noted, to the House of Representatives the "sole Power of Impeachment" and to the Senate the "sole Power to try all Impeachments." 104 This means that the House exercises exclusive control over whether to impeach and which articles of impeachment will be presented to the Senate at trial. ${ }^{105} \mathrm{~A}$ number of different triggers have led to impeachment investigations, including allegations made by Members, recommendations of an investigating House committee, requests from the President, "charges transmitted from the legislature of a state or territory or from a grand jury," or by recommendation of the Judicial Conference of the United States. ${ }^{106}$

In deciding whether to pursue articles of impeachment against a person, at least two preliminary questions must be addressed. First, is the person the President, Vice President, or a civil officer-and therefore an impeachable person - as contemplated by the Constitution? ${ }^{107}$ Second, does the person's conduct constitute treason, bribery, or other high crimes or misdemeanors, or alternatively, is the conduct impeachable? ${ }^{108}$ This second question is where much of the deliberation occurs, and will be revisited below. To answer this question, the House Judiciary Committee must perform an investigation and report to the House with a recommendation. ${ }^{109}$ Regardless of the recommendation, the House may then vote, with a simple majority required to adopt the articles. ${ }^{110}$ Once the articles are adopted, the House appoints impeachment Managers (from the House) to conduct the case against the impeached party in the Senate trial. ${ }^{11}$ The House managers may also engage counsel to assist in the trial process. ${ }^{112}$

2. The Role of the Senate.-The House then sends a message informing the Senate of the impeachment and asking that the Senate prepare for trial. ${ }^{113}$ The Senate responds to the message with a time at which the Managers should appear before the bar of the Senate to verbally impeach the party and demand a trial. ${ }^{114}$ Before sitting as a Court of Impeachment, the Constitution requires that all

104. U.S. Const. art. 1, §§ 2-3; see also Impeaching Federal Judges, supra note 97, at 1; SMELCER, supra note 98 , at 3.

105. BAZAN, supra note 96 , at 9.

106. Id. at 9 n.38.

107. Id. at 15 .

108. Id.

109. Id. at 9 n.38.

110. Impeachment, U.S. House of Representatives: History, ART \& ARchives, http://history.house.gov/Institution/Origins-Development/Impeachment/ [https://perma.cc/D33SUQ9T] (Last visited Oct. 9, 2018).

111. List of Individuals Impeached by the House of Representatives, U.S. HousE OF REPRESENTATIVES: HISTORY, ART \& ARCHIVES, http://history.house.gov/Institution/Impeachment/ Impeachment-List/ [https://perma.cc/7K5V-C2ED] (last visited Oct. 9, 2018).

112. T.J. Halstead, Cong. Research Serv., 98-806, An Overview of the Impeachment PROCESS 5 (2005).

113. SMELCER, supra note 98 , at 8 .

114. Id. 
participating members of the Senate take an oath or affirmation. ${ }^{115}$ Further, in the event of a presidential impeachment, the Constitution requires that the Chief Justice of the Supreme Court act as the Presiding Officer in the proceedings. ${ }^{116}$

Where the Constitution is largely silent on the remaining procedures, the Senate relies on the Rules of Procedure and Practice in the Senate When Sitting on Impeachment Trials, which were adopted prior to the impeachment of President Andrew Johnson and have been used for all impeachments, largely unchanged, since then. ${ }^{17}$ The Senate process is notable for its judicial nature, including the issuance of the summons to the impeached party, opening statements by the House Managers and the counsel for the accused, procedures for evidence and the questioning of witnesses, and closing statements. ${ }^{118}$

After the trial the Senate deliberates, usually behind closed doors. ${ }^{119}$ At the end of the deliberation process, the Senate may no longer proceed in a closed session, and must vote by roll-call in open session. ${ }^{120}$ The Constitution requires two-thirds to convict, with anything less resulting in an acquittal. ${ }^{121}$ If the party is convicted. the Senate removal automatically follows, and the Senate may then vote on whether to disqualify the impeached party from holding future office, with only a majority necessary to disqualify. ${ }^{122}$

3. Conclusion of Impeachment Process.-While the above recital of the process may seem lengthy, it is actually an abbreviated description. The relatively short sections of the Constitution addressing impeachment have predictably spawned a great deal of consideration and deliberation by both the House and the Senate. It is particularly worth noting the transformation of the Senate into a quasi-judicial body. Even though the Constitution imposes only three requirements on the Senate, ${ }^{123}$ the body has voluntarily adopted procedurally elaborate Rules for its trials that mirror what one might expect to see in a court. ${ }^{124}$

\section{B. Impeachable Offenses}

What precisely qualifies as an impeachable offense? In the context of impeachable conduct, the Constitution refers to "Treason, Bribery, or other high Crimes and Misdemeanors." 125

Treason is defined in Article III, $\S 3$ of the Constitution as consisting of either "levying War against [the United States]," or alternatively "in adhering to their

115. U.S. CONST. art. I, § 3, cl. 6.

116. Id.

117. SMELCER, supra note 98 , at 5 .

118. U.S. ConST. art. I, § 3, cl. 6; S. Doc. No. 104-1, at 100-27 (1995).

119. SMELCER, supra note 98 , at 15.

120. Id. at 17.

121. U.S. Const. art. I, § 3, cl. 6; S. Doc. No. 104-1, at 120 (1995).

122. SMELCER, supra note 98 , at 18.

123. U.S. CONST. art. I, $\S 3$, cl. 6.

124. See S. Doc. No. 104-1, at 100-27 (1995).

125. U.S. CONST. art. II, § 4. 
Enemies, giving them Aid and Comfort."126 The Section goes on to say: "No Person shall be convicted of Treason unless on the Testimony of two Witnesses to the same overt Act, or on Confession in open Court." 127

One of the first insights came during the Treason and Sedition trial of John Fries in 1800, where he stood accused of Treason for leading a rebellion in response to a direct federal property tax. ${ }^{128}$ Supreme Court Justice Samuel Chase - who would later be impeached in part for his role in this case - instructed the jury that to commit treason, the accused must participate in an insurrection within the United States for the purpose of accomplishing by force or violence "any object of a great public nature, or of public and general (or national) concern." 129 Justice John Marshall expanded on the meaning of levying war in Ex Parte Bollman ${ }^{130}$ and United States v. Burr, ${ }^{131}$ finding that conspiracy to commit treason was not enough, and that some level of force must be threatened or used before a party could be said to levy war. ${ }^{132}$ Finally, Supreme Court Justice Joseph Story suggested that intent, in the form of a "treasonable purpose," is a necessary element. ${ }^{133}$ Therefore, the high bar for treason through levying war would seem to require intent to pursue a treasonable purpose and an overt act taken to carry out that purpose that demonstrates some plausible ability to actually threaten or use force.

The second way a citizen might commit treason is through adhering to and aiding the enemy. Two cases from World War II illuminate the necessary elements. The first, Cramer v. United States, ${ }^{134}$ established that both elements, adhering and aiding, must be satisfied. ${ }^{135}$ The Supreme Court suggested that adhering to the enemy is not enough absent some overt act providing aid or comfort, ${ }^{136}$ nor is taking an action that might be said to aid the enemy if the purpose is not to betray the United States. ${ }^{137}$ In Kawakita v. United States,${ }^{138}$ the Court reiterated the requirements, performing a lengthy analysis of both the intent behind the actions and whether the conduct "actually promoted the cause of the enemy." 139 Once again, the standard is high and requires both intent to support an enemy and an effective overt act that provides aid.

126. U.S. CONST. art. III, $\S 3, \mathrm{cl} 1$.

127. Id.

128. See Case of Fries, 9 F. Cas. 924, 944 (C.C.D. Pa. 1800) (No. 5127).

129. Id. at 930.

130. Ex Parte Bollman, 8 U.S. 75 (1807).

131. United States v. Burr, 25 F. Cas. 2 (C.C.D. Va. 1807) (No. 14,692a).

132. Ex Parte Bollman, 8 U.S. at 126; United States v. Burr, 25 F. Cas. at 13.

133. In re Charge to the Grand Jury-Treason, 30 F. Cas. 1046, 1047 (C.C.D.R.I. 1842) (No. $18,275)$.

134. Cramer v. United States, 325 U.S. 1 (1945).

135. Id.

136. Id. at 31.

137. Id. at 29 .

138. Kawakita v. United States, 343 U.S. 717 (1952).

139. Id. at 741 . 
Bribery is a concept with substantial legal history. As observed by Justice Story in his COMMENTARIES ON THE CONSTITUTION, it is a concept that can be interpreted by resort to the common law. ${ }^{140}$ In exploring English precedent, Blackstone suggested that bribery occurs when an official accepts "any undue reward to influence his behavior in his office."141

Bribery also has a long statutory history. The very First Congress enacted a statute criminalizing the acceptance by judges of anything of value in exchange for making a favorable judgment or disposition. ${ }^{142}$ This statute survives to this day. ${ }^{143}$ In its current iteration, it covers public officials and employees of the United States government, and criminalizes the acceptance of anything of value in exchange for "being influenced in the performance of an official act," assisting in a fraud on the United States, or violating an official duty. ${ }^{144}$ The scope of this statute has been most recently explored in McDonnell $v$. United States, ${ }^{145}$ where the court found that "[t]o qualify as an official act, the public official must make a decision or take an action on [a] question, matter, cause, suit, proceeding or controversy, or agree to do so."146 While this likely limited the scope of the statute, the Court left the statute largely intact by declining to find that it was unconstitutionally vague. ${ }^{147}$

The phrase "high Crimes and Misdemeanors" is not immediately or intuitively obvious. Understanding this clause requires a look at its history.

1. English Precedent.-An English impeachment that occurred contemporaneously with the Constitutional Convention was that of Warren Hastings. ${ }^{148}$ Three days before the Convention convened, the House of Commons impeached Hastings for "high crimes and misdemeanors." The charges against Hastings, who was previously the governor of India, included "mismanagement and misgovernment in India, including acts of extortion, bribery, corruption, confiscation of property, and mistreatment of various provinces."149 In arguing at the Convention that an earlier draft of Article II, Section 4 that limited impeachment to "treason and bribery" was too narrow, George Mason of Virginia observed that Hastings' actions might not have been captured by such narrow language. ${ }^{150}$ Mason suggested the use of the "high crimes and misdemeanors"

140. Joseph Story, Commentaries On The Constitution 561-62 (Thomas M. Cooley ed., 1873).

141. IV William Blackstone, Commentaries On The Laws Of England 136-39 (1769).

142. Crimes Act of 1790,1 Stat. 112, 117.

143. See 18 U.S.C. $\S \S 201(2)(a)-(c)(2019)$.

144. Id.

145. McDonnell v. United States, 136 S. Ct. 2355 (2016).

146. Id. at 2372 (internal quotations omitted).

147. Id. at 2375 .

148. John D. Feerick, The Hastings Impeachment, Acquittal, N.Y. L. J., May 28, 1974, at 1.

149. Impeaching Federal Judges, supra note 96, at 9; see also GeORGe Robert Gleig, Memoirs of the Life of the Right Hon. Warren Hastings 283-85 (1841); P. J. Marshall, THE IMPEACHMENT OF WARREN HASTINGS (1965).

150. 2 The Records of the Federal Convention of 1787, at 550 (Max Farrand ed., 1911). 
expression, and it was ultimately adopted as part of the Constitution. ${ }^{151}$

In approximately forty English cases spanning more than four hundred years, convictions for high crimes and misdemeanors "involved acts of a criminal nature, grave misuse of one's official position, or treasonous-like conduct."152 While many of these cases involved a violation of statutory or common law, a violation of positive law did not appear to be a prerequisite to impeachment. ${ }^{153}$ The cases offer little precedent, however, supporting the impeachment of "an official for conduct not constituting either a crime or gross abuse of official duties." $" 154$

2. The Constitutional Convention.-The 1787 debates "reveal that the primary concern of the Framers was not acts that could be committed by any citizen, but rather acts associated with the exercise of a public trust that could endanger the nation." 155

James Madison expressed concern that the President "might pervert his administration into a scheme of peculation or oppression. He might betray his trust to foreign powers." ${ }^{156}$ Edmund Randolph of Virginia worried that "[t]he Executive will have great opportunit[ies] of abusing his power; particularly in time of war when the military force, and in some respects the public money will be in his hands." 157 George Mason justified the expansion of the impeachment powers in part based on the Constitutional prohibition on Bills of Attainder, ${ }^{158}$ which had been used by the British Parliament to punish by simply legislating that a named individual should be punished. ${ }^{159}$ Mason argued that since the Bills of Attainder were prohibited, it was appropriate to expand the impeachment powers. $^{160}$

The Framers were also influenced by the early state constitutions, ${ }^{161}$ which provided for impeachment to remedy misconduct with regards to the duties of public office. ${ }^{162}$ All of this suggests that the expression high crimes and misdemeanors reaches a specific form of misconduct: the abuse of, or severe misbehavior, while holding an official position to the detriment of the nation and

151. Impeaching Federal Judges, supra note 97, at 49.

152. Id. at 8 .

153. Id. at 49 .

154. Id.

155. Id. at 50 .

156. Id. at 18 .

157. Id. at 19 .

158. Impeaching Federal Judges, supra note 97, at 22; 2 The ReCORDS OF THE FEDERAL CONVENTION OF 1787, supra note 150 at 550.

159. Kenneth R. Thomas, Cong. Research Serv., R40826, Bills of Attainder: The COnstitutional Implications of CONGRESS Legislating NARRowly 3 (2014); Impeaching

Federal Judges, supra note 97, at 6 n.25.

160. Impeaching Federal Judges, supra note 97, at 22; 2 The ReCORds of THE FEDERAL CONVENTION OF 1787, supra note 150, at 550.

161. Impeaching Federal Judges, supra note 97, at 15.

162. Id. at 49 . 
the integrity of the Constitution. ${ }^{163}$

3. Past Impeachments.-The impeachment powers have been used sparingly across our history. Only nineteen persons have been impeached in the history of the United States, including two presidents, one senator, one Cabinet member and fifteen judges, one of whom was a Supreme Court justice. ${ }^{164}$ Of those impeached, one, Senator William Blount, had no Senate trial due to lack of jurisdiction, and three others resigned either before the Senate trial commenced or before its completion. ${ }^{165}$ Of the remaining fifteen, seven were acquitted after trials in the Senate, and eight, all judges, were found guilty after trials. ${ }^{166}$ They were removed from office and three of them were disqualified from holding future office. ${ }^{167}$

a. Judicial impeachments.-The judges' proceedings offer some insight into what constitutes "high crimes and misdemeanors." Three who were removed were indicted for crimes before they were impeached. ${ }^{168}$ Those three were Harry Claiborne in 1986 after indictment for and conviction of income tax invasion, Alcee Hastings in 1989 after indictment for and acquittal of bribery and perjury, and Walter Nixon in 1989 after indictment for and conviction of making false statements to a grand jury. ${ }^{169}$ Another judge, Thomas Porteous, was investigated by the Department of Justice and ultimately impeached and convicted in 2010 for accepting bribes and making false statements under penalty of perjury, though he was never actually indicted. ${ }^{170}$ Judges Claiborne and Nixon were impeached and convicted for wrongful conduct that does not appear directly linked to an abuse of office. ${ }^{171}$ However, these two exceptions might be explained by a reluctance on the part of Congress to allow judges who had been sentenced to prison, and who refused to resign their posts, to continue collecting their salaries and return to the bench after serving their sentences. ${ }^{172}$ The two others, Hastings and Porteous, appeared to have misused their offices to solicit and accept bribes in addition to their potentially illegal behavior. ${ }^{173}$

Of the remaining four judges who were convicted by the Senate, John Pickering was impeached in 1803 and convicted in 1804 for both intoxication on the bench and the unlawful handling of property claims, West H. Humphreys was impeached and convicted in 1862 for refusing to hold court and waging war against the United States, Robert Archbald was impeached in 1912 and convicted

163. StafF of H. COMm. On the Judiciary,93D CONG., ReP. On CONSTitutional Grounds FOR PREsidential IMPEACHMENT 1-27 (Comm. Print 1974).

164. List of Individuals Impeached by the House of Representatives, supra note 111.

165. Id.

166. Id.

167. Id.

168. Id.

169. Michael J. Gerhardt, Lessons of Impeachment History, 67 GEO. WASH. L. REV. 603, 614 (1999).

170. H.R. ReP. No. 111-427 (2010).

171. Gerhardt, supra note 169, at 613-14.

172. Id.

173. See H.R. ReP. No. $111-427$ at 2. 
in 1913 for improper business relationships with litigants, and Halsted Ritter was impeached and convicted in 1936 for favoritism in appointing bankruptcy receivers and for practicing law as a judge. ${ }^{174}$ Significantly, these latter four were all impeached and convicted for activities that, while not necessarily statutorily illegal, constituted an abuse of their positions.

b. Presidential impeachments.- Only two presidents, Andrew Johnson and William Clinton, have been impeached by the House. ${ }^{175}$ Richard Nixon also merits inclusion in an analysis of presidential impeachment, as his impeachment was imminent after the House Judiciary Committee voted to recommend three articles of impeachment, ${ }^{176}$ but was avoided through resignation. ${ }^{177}$

President Johnson was impeached for violating the Tenure in Office Act by removing and replacing his Secretary of War, and for attempting to undermine Congressional authority. ${ }^{178}$ Some of his articles of impeachment were linked to the use of the executive power in a way Congress asserted was illegal. ${ }^{179}$ The allegations that Johnson undermined Congressional authority implicated the use of his position to harm another branch. Johnson's counsel argued that without some law and a criminal intent to violate that law, conviction would be inappropriate as an unconstitutional Bill of Attainder. ${ }^{180}$ Johnson was ultimately acquitted in the Senate trial thirty-five yes votes to nineteen no votes, one vote shy of the necessary two-thirds for conviction. ${ }^{181}$

In drafting the articles for the Nixon impeachment, the House Judiciary Committee seemed to believe that an abuse of power was necessary, and asserted that he

abused the powers of his office, causing "injury to the confidence of the nation and great prejudice to the cause of law and justice," and resulting in subversion of constitutional government; that he failed to carry out his constitutional obligation to faithfully execute the laws; and that he failed to comply with congressional subpoenas needed to provide relevant evidence for the impeachment investigation. ${ }^{182}$

A minority of the House Committee asserted that errors of administration were

174. List of Individuals Impeached by the House of Representatives, supra note 111.

175. Id.

176. Richard Lyons \& William Chapman, Judiciary Committee Approves Article to Impeach President Nixon, 27 to 11, WASH. Post, July 28, 1974, at A01.

177. BAZAN, supra note 96 , at 9.

178. Staff of H.R. Comm. on the Judiciary, 93D Cong., Impeachment, Selected MATERIALS 154-61 (1973).

179. Id. at 156 .

180. Impeaching Federal Judges, supra note 97, at 35-36.

181. The Senate Votes on a Presidential Impeachment, U.S. SENATE, https://www.senate.gov/ artandhistory/history/minute/The_Senate_Votes_on_a_Presidential_Impeachment.htm [https://perma.cc/42FG-BEJF] (last visited Oct. 10, 2018).

182. BAZAN, supra note 96, at 26 (quoting 3 Deschler's PreCedents of THE U.S. House of REPRESENTATIVES $§ 3.7$, p. 1980). 
insufficient, seeming to suggest that crimes or actions with criminal intent are necessary to an impeachment. ${ }^{183}$

In the Clinton impeachment, the Republican majority of the House appeared to express the view that misconduct unrelated to the exercise of power was sufficient since it "undermined the integrity of his office, . . . brought disrepute on the Presidency, ... betrayed his trust as President, and ... [was] subversive of the rule of law and justice, to the manifest injury of the people of the United States." "The Democratic minority, on the other hand, asserted "that the allegations that the President violated criminal laws in attempting to conceal that relationship - even if proven true - [did not] amount to the abuse of official power which is an historically rooted prerequisite for impeaching a President." 185 The Senate subsequently acquitted Clinton, with forty-five votes to convict and fifty-five opposed on the first article for perjury and a fifty to fifty vote on the second article for obstruction of justice, perhaps indicating that the charges of personal misconduct were not constitutionally sufficient, or perhaps indicating a vote largely along party lines. ${ }^{186}$

4. Evaluating the Grounds for Impeachment.-Some argue that the Constitution contemplated "a broad definition of impeachable offenses . . . [encompassing] any act - including non-criminal conduct - that would bring disrepute upon the office." ${ }^{, 187}$ Under this view, removal can be proper for noncriminal, private behavior that brings disrepute upon the person and office. ${ }^{188}$

Some go even further. Congressman Ford once famously said, during the impeachment discussion regarding Justice Douglas of the United States Supreme Court, that "an impeachable offense is whatever a majority of the House of Representatives considers to be at a given moment in history; conviction results from whatever offense or offenses two-thirds of the other body considers to be sufficiently serious to require removal of the accused from office." ${ }^{189}$ His statement was the catalyst for my undertaking a study of presidential impeachment.

Others have argued that for impeachment to be proper, the public official must (1) exceed their constitutional power to the detriment of another branch of government; (2) behave in a manner grossly incompatible with the office; or (3) use their power for an improper purpose or for personal gain. ${ }^{190}$ The first and last share a common feature: The conduct is linked to the exercise of the powers of

183. BAZAN, supra note 96, at 26 (citing H.R. REP. No. 93-1305, at 362-72, printed at 120 Cong. ReC. 29312-15 (1974)).

184. H.R. Res. 611,105 th Cong. (1998).

185. H.R. REP. No. 105-830, at 200 (1998).

186. 145 CONG. REC. S1459 (daily ed. Feb. 12, 1999).

187. Jonathan Turley, The Executive Function Theory, the Hamilton Affair, and Other Constitutional Mythologies, 77 N.C. L. REV. 1791, 1840 (1999).

188. Id. at 1844 .

189. 116 CONG. REC. 11,913 (1970) (remarks of Rep. Gerald Ford).

190. StafF Of H. Comm. On the Judiciary, 93d Cong., ReP. On Constitutional Grounds for Presidential Impeachment 18 (Comm. Print 1974). 
the office. The second seems to retain the possibility that private misconduct may be grounds for impeachment. But it is argued that such misconduct must be particularly heinous to qualify. ${ }^{191}$

Nearly fifty years ago, as noted, I wrote an article responding to Congressman Ford's statement about the breadth of Congressional authority to impeach. I had the help of a Fordham Law School student, Robert Quinn, and a young colleague at Skadden Arps, Edward Yodowitz, which made the article possible. Senator Sam Ervin of North Carolina placed the article in the Congressional Record and later wrote to one of my law partners, stating, "I was honored to place in the Congressional Record the excellent law review article written by your partner . . . I have never seen a piece of work in this area which displayed the scholarly research and painstaking analysis as does the article by Mr. Feerick." ${ }^{192}$ Later, Ervin would chair the Senate Impeachment Study Committee.

Drawing on English history, the Constitutional Convention, and subsequent impeachments, I argued that "[i]n framing the impeachment provisions, the concern of the framers was not limited to crimes of which private citizens and public officials could be equally guilty," but rather contemplated "the abuse or betrayal of a public trust, offenses peculiar to public officials." ${ }^{\prime 193}$ I reasoned that impeachable offenses were neither limited to indictable offenses nor did they extend to non-indictable offenses unconnected with the use of official power. ${ }^{194}$

I argued that for conduct to be impeachable, "[i]t must violate some known, established law, be of a grave nature, and involve consequences highly detrimental to the United States," or that, "[i]n the alternative, it must involve evil, corrupt, willful, malicious or gross conduct in the discharge of office to the great detriment of the United States." ${ }^{195}$ I did not believe that the grounds for impeachment should be broadened to encompass purely personal misconduct, not because such misconduct should be protected, but out of a concern for the independence of the Judiciary and Executive. ${ }^{196}$ I suggested in my article that the "process of removing should be made as difficult as possible, though not to the extent of leaving the nation powerless to remove an official who betrays his public trust." ${ }^{197}$ Ultimately, I advocated for such a standard because I believed that limiting the grounds for impeachment was the necessary price to prevent the abuse of impeachment to crush adversaries or remove them from office. ${ }^{198}$ Then, as now, "[n]othing could be more destructive of our system of government."199

191. Background and History of Impeachment: Hearing Before the Subcomm. on the Constitution of the H. Comm. on the Judiciary, 105th Cong. 89 (1998) (Written Testimony of Professor Cass Sunstein).

192. Letter from Sam Ervin, former N.C. Sen. to John D. Feerick (on file with author).

193. Impeaching Federal Judges, supra note 97, at 53.

194. Id. at 54 .

195. Id. at 54-55.

196. Id. at 58 .

197. Id.

198. Id.

199. Id. 


\section{CONCLUSION}

The provisions on presidential succession and impeachment are designed to keep the country safe, with a successor in the wings if a succession event occurs, and protected if a President violates the specific grounds set forth in the Constitution. In one case a sitting President may be removed from his powers and duties and in the other case he may be removed from office and disqualified from holding future office. In both cases the removal is made difficult so as to respect the voice of the people in choosing a president. In one case it takes a two-thirds vote of each House of Congress to remove a President against his will and in the other a two-thirds vote of the Senate, after a trial presided over by the Chief Justice of the Supreme Court. In the long history of the country neither event has happened. How fortunate the American democracy is to have had such a history. But if the nation does ever encounter a situation where a president is removed from office, it will be more prepared as a result of the experiences and accomplishments of Indiana public servants. 


\section{APPENDIX A}

The following excerpts are from a telephone interview of former Vice President Dan Quayle that the author of this article conducted on July 24, 2018.

\section{Indiana's Vice Presidents:}

John Feerick: I was just curious as a starter, any reflections on the Indiana history with respect to the subject of presidential succession?

Dan Quayle: Well we had had six vice presidents, you know second only to the state of New York.

JF: Yes and actually I think one of them, [Schuyler] Colfax, is used in the count of both states.

[Laughter]

DQ: There's a lot of interesting history of Vice Presidents. You know the first Indiana Vice President was Colfax. He had an interesting ride, as Grant's Vice President. I think historically Grant was quite good, but he had a lot of problems with nepotism and things like that.

Meeting called by President George H.W. Bush in April 1989 to plan for uses of the Twenty-Fifth Amendment:

DQ: The meeting was initiated by [White House Counsel] Boyden Gray. He served eight years as counsel to Vice President Bush. I think there was a feeling that this issue wasn't adequately addressed in the Reagan administration. That was very interesting hence Reagan had had an assassination attempt. When the Bush team took over this was one of the first things they did. It was in the first several months of the administration where we had the meeting on Presidential succession. Boyden had all the documents. He went through it all, how it would work. The meeting probably lasted maybe an hour and everyone knew what the situation was and that was it. I don't think we ever had any subsequent meeting on that issue. We wanted everyone in the room to agree to how this was all going to work.

JF: In the literature, there's some, I might say, confusion as to whether or not at that meeting the general discussion got embodied in some kind of document. I know there was a press conference later that month by [White House Press Secretary Marlin] Fitzwater, as I recall, and he said, my recollection is, that there were no agreements, but one of the doctors somehow suggested that there was. Do you have any recollection whether there was any understanding of approaches that got embodied in some kind of writing? 
DQ: No, there was no signed document if you will. We just didn't work like that. But clearly Boyden had documents that would be implemented if the situation occurred. So there were documents.

Potential presidential inability scenarios during Vice President Quayle's term:

JF: I mention in my book on the Twenty-Fifth Amendment, in May of 1991 there was an irregular heartbeat issue that President Bush suffered and then the president fell ill in Japan in 1992, but both occasions he seemed to jump right back. In those situations, do you have any recollection as to whether or not you were communicated with about them?

DQ: Well in both situations I communicated with the Chief of Staff. That's the way it works. The Japan event resolved itself fairly quickly because I picked up the phone and called Barbara and said, "What going on over there?" She said he just overdid it, he's just got a touch of the flu. It was four o'clock in the morning Washington time. She said, "Go back to bed everything's fine." I said, "Okay." I called the Chief of Staff and said, "Calm down. Everything's okay."

The other issue is when a president undergoes an anesthetic. The question is do you implement the Twenty-Fifth Amendment or not. We had a discussion about that when President Bush had a particular medical procedure. I think there were documents prepared to do it and then at the end of the day we decided not to do it. It was a fairly short time that he was going to be incommunicado. This underscores how detailed, thoughtful that Boyden and his crew really were on this issue. After serving as Vice president for 8 years, the Bush team believed the presidential succession needed more thought, detail, documents, etcetera.

Vice President Quayle's role as the next person in line to presidency:

JF: As a generalization, did you have any feelings at the time about the prospect of potentially having to decide whether the president was disabled and serving as acting president?

DQ: Well it's not a decision of one. There was a lot of collegiality in the Bush administration and what you do is you really rely on his people for the consensus. That's what I did when there was a discussion of whether there should be this transfer of power. I said, "You decide and just let me know." And that's the way it worked. Now if you have a more permanent situation than going under anesthesia, that's a different issue.

JF: Right, in your context it was the former. 
DQ: Right.

JF: And you weren't getting any information that indicated that it was other than what was being described.

DQ: Correct. 